This is a self-archived version of an original article. This version may differ from the original in pagination and typographic details.

Author(s): Lievonen, Matias; Luoma-aho, Vilma

Title: Ethical Hateholders and Negative Engagement. A Challenge for Organisational Communication

Year: 2015

Version:

Copyright: (C) P.I.E. PETER LANG S.A.

Rights: In Copyright

Rights url: http://rightsstatements.org/page/InC/1.0/?language=en

Please cite the original version:

Lievonen, M., \& Luoma-aho, V. (2015). Ethical Hateholders and Negative Engagement. A Challenge for Organisational Communication. In A. Catellani, A. Zerfass, \& R. Tench (Eds.), Communication Ethics in a Connected World : Research in Public Relations and Organisational Communication (pp. 285-303). Peter Lang Publishing Group. https://doi.org/10.3726/978-30352-6555-2/27 


\title{
Ethical hateholders and negative engagement: A challenge for organisational communication
}

\author{
MATIAS LIEVONEN \& ViLMA LUOMA-AHO
}

University of Jyväskylä, Finland

Negative stakeholder emotions have become an urgent topic for organisations. Negatively engaged stakeholders or hateholders are challenging due to their strong emotions and ability to harm the organisation through sharing negative experiences online. Hateholder behavior affects organisational reputation and may also cause increasing negative word-of-mouth, activism and boycotts. This preliminary conceptual study looked at what causes negative engagement online and turns stakeholders into hateholders. Through a literature review on stakeholder and customer anger, the chapter asks what role organisations and ethics play in creating stakeholder anger. By applying the TARES framework, the goal was to distinguish different ethical breaches of organisations. The results yielded that most common organisational faults included lack of respect and fairness. Results also showed that in most hateholder cases, the organisations themselves were somehow to blame. This seems to highlight the lack of strategic thinking of organisations. Thus, the chapter also calls for more dialogue and interaction with stakeholders in cases of anger.

\section{Introduction}

Recent research has suggested the public sphere to be increasingly established, maintained, and controlled by organisations (Bentele \& Nothaft, 2010). While this implies the need for stakeholders to better engage with organisations, stakeholder engagement has only recently received attention from scholars (van Doorn et al., 2010). Stakeholder engagement matters as meanings are created through interaction with the organisation, and engagement is often accompanied by strong experiences and emotions for better or worse. In the online world, both positive and negative stakeholder engagement is now more visible than 
before, making understanding stakeholder emotions a priority for organisations (Vivek et al., 2012; Brodie et al., 2011). Most research so far has concentrated on the positive side of stakeholder engagement. Yet negative stakeholder engagement is important as well, as it can lead to disengagement and severe organisational losses.

Negative engagement has gained importance due to empowered stakeholders sharing their emotions and experiences online (Coombs \& Holladay, 2005). Especially of interest for negative engagement is the formation of negative emotions, which could lead to stakeholder anger and result in losses for the organisation (Coombs \& Holladay, 2007; 2012). We call stakeholders of negative experiences and emotions hateholders (Luoma-aho, 2008, 2010), due to their ability to harm the organisation and its reputation. Stakeholders become hateholders once their negative engagement is public. Previous studies have shown that anger is a central emotion in the process of becoming a hateholder. Anger works in several ways, from influencing purchase intention and operating as a catalyst for negative word-of-mouth (Coombs \& Holladay 2007: 301). It also affects organisational reputation and may cause activism and boycotts (Lindenmeier et al., 2012).

Building on Hirschman (1970), stakeholder anger may result in either ending the relationship (exit) or uttering complaints in order to change the situation (voice). Voice can be understood as feedback and venting, and in the present online environment it often takes the shape of negative electronic word-of-mouth (Zeelenberg \& Pieters, 2004). In extreme cases, anger can lead to attempts to hurt the service provider (Zeelenberg \& Pieters, 2004) and even sabotage is possible (McCollKennedy et al., 2011). A connection between anger and anti-corporate activism has been established, but the logic behind anger is not always obvious and it means that organisations' ability to react on the anger of stakeholders still remains questionable (Simola, 2009). Anger is not a new emotion, but public relations literature has mostly approached it in the context of crises (Coombs \& Holladay, 2007). A recent edition of the European Communication Monitor (Zerfass et al., 2013) shows that most public relations practitioners face crises annually, and that the grounds for these crises include ethical issues. In fact, $17 \%$ of the reported crisis situations across Europe were related to management where ethics was an important aspect. Less attention has been directed toward the causes of stakeholder anger, and especially to the organisational actions and ethically questionable behaviour contributing to negative engagement.

Ethics is becoming increasingly important for communication professionals dealing with engaged stakeholders (Hickson, 2003), and simultaneously many problems organisations have with stakeholders are 
related to ethics. To understand the role of ethical problems for negative stakeholder engagement, a look at previous literature on stakeholder anger was helpful. Because organisations are challenged by angry stakeholders (Brodie et al., 2013; McColl-Kennedy et al., 2011; Simola, 2009), it is important to explore stakeholder experiences and, in this case, the ethical issues leading to anger. To study ethics, the TARES framework has been applied. The purpose of this chapter is to focus on negative engagement, which is a central topic for public relations, as negative emotions resulting from discordant relationships may hinder future interaction with the organisation (Loewenstein. 1996). Especially the online environment has given rise to negative emotions (Smith et al., 2013) and many negative outbursts are related to venting those (Parlamis, 2012). Negative emotions often have a clear source, and this study analysed the different grounds leading to negative stakeholder emotions. The questions guiding the research were:

RQ1: How can negative engagement be defined? What are organisational hateholders?

RQ2: What is the role of ethical problems of organisations behind stakeholder anger?

This chapter is organised as follows: First, hateholders and negative engagement are introduced. Second, the importance of ethics for public relations is discussed and the TARES framework is discussed. Conclusively in the third section, unethical persuasion leading to a negative engagement is introduced. Next, the results of the literature review are examined and the role of ethics for hateholder activity is addressed. At the end of the article, hateholders are categorised. Last but not least, theoretical and practical implications are discussed.

\section{Negative engagement and hateholders}

Stakeholder engagement occurs as a result of multiple cognitive and behavioural aspects (Brodie et al., 2011). Stakeholder's behavioural and attitudinal dimensions shape the relationship, and previous studies have suggested participation and involvement to be seen as required elements associated with engagement (Vivek et al, 2012; Brodie et al., 2011). Brodie et al. (2011) separated engagement from other participative and involvement actions by underlining the role of stakeholders' experiences with certain objects of engagement (e.g. an organisation). From this perspective, experiences provide the baseline of engagement, though it is possible to view engagement merely as a psychological state only through, for example, para-social relationships.

Organisation-stakeholder relationships have multiple levels and the organisational service setting is a platform for both positive and negative 
stakeholder experiences. Stakeholders' experiences consist of individual responses and perceptions, how the event fits the individual's life (Calder et al., 2009). Engagement with organisations may be triggered by stakeholders' own or mediated experiences (Mersey et al., 2010). As the experiences occur and are ruminated by the stakeholders, constituencies for engagement are formed (Brodie et al., 2013; Vivek et al., 2012; Brodie et al., 2011; Mollen \& Wilson, 2010; Calder et al., 2009). In addition, negative experiences might even lead to anger, which is one of the most powerful behavioural triggers that affect stakeholders negatively.

Anger can be defined as an emotion (Simola, 2009) which can be expressed through actions (Simola, 2009; Turner, 2007; Coombs \& Holladay, 2007). In fact, the way anger is expressed determines its influence on an organisation. For organisations, stakeholder anger can be severely problematic depending on how it is experienced, understood, and expressed (Simola, 2009). The power of anger is obvious: anger can be a catalyst for negative word-of-mouth and purchase intentions, and it can energize people to boycott or lobby against a product or a service (Coombs \& Holladay, 2007).

For angry stakeholders, placing blame on someone or something is important (Stein \& Levine, 1990). Although anger may result in disengagement or exit, it is seldom left undiscussed on the social networks of the stakeholder, and in many behavioural responses to negative experiences, negative word of mouth is quite common (Zeelenberg \& Pieters, 2004). Because of this organisations are increasingly more aware of public discussions taking place on different issue arenas (Luoma-aho \& Vos, 2010) such as social networking sites (Coombs \& Holladay, 2007). Being aware, however, does not mean that the organisation can respond to or knows how to handle the hateholders.

Actual participative actions from a stakeholder are required for the interaction to be considered engagement. We define negative engagement online as an experience-based series of participative actions in online environments where negative issues concerning an organisation or brand are publicly discussed. We propose that only public negative stakeholder actions count as negative engagement, as without public view they are less harmful to organisations. Content creation can be seen as the highest level of engagement in online environments (Muntinga et al., 2011). Negative experiences might lead to anger and activate the stakeholder to begin creating content online. In such cases the stakeholder becomes a hateholder (Luoma-aho, 2010), an angry stakeholder who publicly shares his/her personal or mediated negative experiences, thus hindering the organisation in some tangible or intangible way. Luoma-aho (2010: 5) argues that "hateholders are 
formed when the distrust and negative emotion that stakeholders feel toward an organisation are strong enough to hinder it." Actions of a hateholder can be seen as public manifestations of the negative emotions experienced. Though this definition focuses on experiences, there are also some other forms of hateholding that include no such grounds such as trolling.

Connectivity and position shape the amount of negative influence a stakeholder has online: the better the stakeholder is positioned in an online environment, the more power and urgency his/her complaints carry (Sedereviciute \& Valentini, 2011). All influence, however, is not created equal, and we argue that negative engagement is especially influential as negative reports are generally more credible than positive ones (Chen \& Lurie, 2013).

\section{Ethics and public relations practice}

Ethics are increasingly important in interaction with stakeholders, who hold different expectations about what is considered ethical. The fundamental idea behind ethics is to distinguish between right and wrong, or on what grounds the judgment of human action is justified (Kizza, 2013). According to Kizza (2013: 16): "a decision is morally good if the result from it is good." However, the ethical problems do not necessarily follow a certain pattern or rules, and they cannot be solved like issues in structured environments (Kizza, 2013) further complicating the organisational choices.

For employees, ethics can emerge through instructions, references and guidelines. Organisational codes of conduct forms the ethical principles and legal instruments enforce good conduct through courts (Kizza, 2013). Public policies may include aspects of acceptable behaviour and norms of a society or a group. However, acceptance of existing ethical guidelines by individuals may vary. Swenson-Lepper (2005) claims the level of education and organisational membership affect the level of ethical sensitivity. Moreover, individuals with higher organisational commitment are less likely to engage in ethically questionable actions, regardless of whether the behaviour benefits or harms the organisation (Cullinan et al., 2008).

Ethical theories describe the various environments where ethical decisions and judgments are made. The theories also draw some conclusions on what actually is considered ethical in theory and practice. Messina (2007) approaches the topic from the perspective of ethical persuasion by examining unethical propaganda, noting that there is no "absolutist approach" (Messina, 2007), and merely principles such as honesty and fairness are the basics of ethical persuasion. The ethical 
pillars for PR practitioners are understood to include truthfulness, not harming, doing good and respecting confidence/privacy (Parsons, 2004). For ethical advocacy, Baker and Martinson (2001) present the TARES framework consisting of truthfulness, authenticity, respect, equity and social responsibility as the standards of ethical persuasion. Propaganda is often related to persuasion and the two types of communication might not be distinguished (Fawkes, 2007). Moreover, Fawkes (2007) notes that persuasion is polar opposite to negotiation, and hence unethical.

Dialogue is understood as the most ethical form of communication (Kent \& Taylor, 2002). Dialogue refers to a two-way interaction which benefits both the organisation and the stakeholders. However, there could be a serious gap between the actions of the organisation and the stakeholder's expectations on ethics. In addition, the ethical problems could be unpredictable and awaken unexpected stakeholders and their emotions (Kizza, 2013; Luoma-aho \& Paloviita, 2010).

\section{Literature review on stakeholder anger}

Data used in this study was originally gathered for a literature review, which was conducted on previous studies published on stakeholder and customer anger. The aim of the review was to explore the issues related to anger toward organisations. A total of 11,071 articles were collected, out of which 150 were considered most relevant and were read. Of these, 59 articles with the most potential were selected for further review to ascertain how many of them would be appropriate for inclusion in the final review. Finally, the data of the literature review comprised 24 articles in 18 different journals.

According to the findings of the literature review, multiple issues contribute to negative stakeholder engagement behaviours. Indeed, before negative behaviours manifest, stakeholders and customers experience different negative emotions toward the organisations. Figure 1 illustrates the different themes emerging from the literature, both the negative emotions of the stakeholders and the negative engagement. The malice form of negative engagement, trolling, was not apparent in any of the cases, but this may simply be a limitation of the search words or the rarity of research on the topic. 
Figure 1. Stakeholder emotions and forms of negative engagement identified in the articles analysed

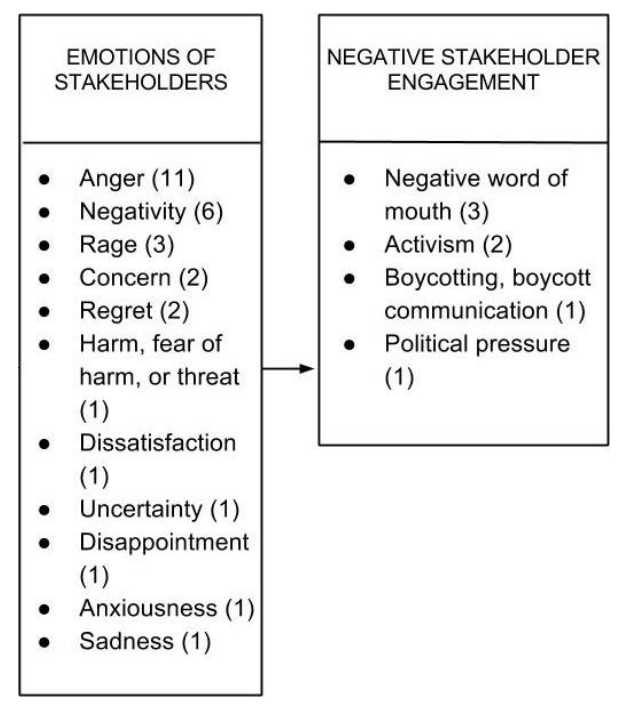

Depending on their perspective, the issues behind the stakeholders' anger found in the literature review were derived from their experiences (Brodie et al., 2013). An experience of a stakeholder is essentially the beginning of the engagement process, and if it progresses to anger, it activates people to negative engagement. Usually, the issues leading to anger reflect the apology, justice, or compensation the stakeholder courts. Naturally, the experiences stakeholders confront could also have other emotional consequences, but the main focus of this study was on the connection between stakeholder anger and ethical breaches. It is important to recognize that certain issues do not always lead to anger, and that there is a possibility that different emotions lead to alternative forms of engagement. The issues introduced in the literature review were analysed for ethical aspects through content analysis. Table 1 introduces the articles and the degree of organisational control or fault for stakeholder anger. 


\section{Table 1. Articles in the literature review organised according to the degree of organisational control or fault for stakeholder anger}

\begin{tabular}{|c|c|}
\hline Article reviewed & $\begin{array}{c}\text { Degree of } \\
\text { organisational control } \\
\text { over issue/fault for } \\
\text { stakeholder anger }\end{array}$ \\
\hline $\begin{array}{l}\text { Alkayid, K., Hasan, H \& Meloche, J. A. 2009. Simulating } \\
\text { information exchanges to investigate the utility of public web } \\
\text { sites. Transforming Government: People, Process and Policy, } \\
\text { Vol } 3 \text { No 3, pp. 271-288. }\end{array}$ & High \\
\hline $\begin{array}{l}\text { Coombs, W. T. \& Holladay, S. J. 2012. Amazon.com's Orwellian } \\
\text { nightmare: exploring apology in an online environment. Journal } \\
\text { of Communication Management, Vol } 16 \text { No 3, pp. 280-295. }\end{array}$ & High \\
\hline $\begin{array}{l}\text { Dhir, K. 2006. Corporate communication through nonviolent } \\
\text { rhetoric. Corporate Communications: An International Journal, } \\
\text { Vol } 11 \text { No 3, pp. 249-266. }\end{array}$ & High \\
\hline $\begin{array}{l}\text { Ihlen, O. \& Berntzen, O. 2007. When lobbying backfires: balan- } \\
\text { cing lobby efforts with insights from stakeholder theory. Journal } \\
\text { of Communication Management, Vol } 11 \text { No 3, pp. 235-246. }\end{array}$ & High \\
\hline $\begin{array}{l}\text { Kerley, R. 2007. Controlling urban car parking - an exemplar for } \\
\text { public management? International Journal of Public Sector } \\
\text { Management. Vol } 20 \text { No 6, pp. 519-530. }\end{array}$ & High/moderate \\
\hline $\begin{array}{l}\text { Kiely, T. 2013. Tapping into Mammon: stakeholder perspectives } \\
\text { on developing church tourism in Dublin's Liberties. Tourism } \\
\text { Review, Vol } 68 \text { No 2, pp. 31-43. }\end{array}$ & High/moderate \\
\hline $\begin{array}{l}\text { Linsley, P.M \& Slack, R.E. 2012. Crisis Management and an } \\
\text { Ethic of Care: The Case of Northern Rock Bank. Journal of } \\
\text { Business Ethics, Vol 113, pp. 285-295. }\end{array}$ & High \\
\hline $\begin{array}{l}\text { McDonald, L.M., Sparks B. \& Glendon, A. I. 2010. Stake- } \\
\text { holder's reactions to company crisis communication and causes. } \\
\text { 2010. Public relations review, Vol 36, pp. 263-271. }\end{array}$ & High/moderate \\
\hline $\begin{array}{l}\text { Pace, K. M., Fediuk, T. A. \& Botero, I. C. 2010. The acceptance } \\
\text { of responsibility and expression of regret in organisational } \\
\text { apologies after a transgression. Corporate Communications: } \\
\text { An International Journal, Vol } 15 \text { No 4, pp. 410-427. }\end{array}$ & High/moderate \\
\hline $\begin{array}{l}\text { Watson, T. 2007. Reputation and ethical behaviour in a crisis: } \\
\text { predicting survival. Journal of Communication Management, } \\
\text { Vol } 11 \text { No 4, pp. 371-384. }\end{array}$ & High \\
\hline $\begin{array}{l}\text { Champoux, V., Durgee, J \& McGlynn, L. 2012. Corporate } \\
\text { Facebook pages: when "fans" attack. Journal of Business } \\
\text { Strategy, Vol } 33 \text { No 2, pp. 22-30. }\end{array}$ & High/moderate \\
\hline $\begin{array}{l}\text { Chen, W., Tsai, D. \& Chuang, H-C. 2010. Effects of missing a } \\
\text { price promotion after purchasing on perceived price unfairness, } \\
\text { negative emotions, and behavioral responses. Social Behavior } \\
\text { and Personality, Vol } 38 \text { No 4, pp. } 495-508 \text {. }\end{array}$ & High/moderate \\
\hline
\end{tabular}




\begin{tabular}{|c|c|}
\hline $\begin{array}{l}\text { Jin, Y., Pang, A. \& Cameron, G. T. 2010. The role of emotions } \\
\text { in crisis responses. Inaugural test of integrated crisis mapping } \\
\text { (ICM) model. Corporate Communications: An International } \\
\text { Journal, Vol } 15 \text { No 4, pp. } 428-452 \text {. }\end{array}$ & Moderate \\
\hline $\begin{array}{l}\text { Lindenmeier, J, Tscheulin, D. K. \& Drevs, F. 2012. The effects } \\
\text { of unethical conduct of pharmaceutical companies on consumer } \\
\text { behavior. Empirical evidence from Germany. International } \\
\text { Journal of Pharmaceutical and Healthcare Marketing, Vol } 6 \text { No } \\
\text { 2, pp. 108-123. }\end{array}$ & Moderate \\
\hline $\begin{array}{l}\text { Sonpar, K., Pazzaglia, F. \& Kornijenko, J. 2010. The Paradox } \\
\text { and Constraints of Legitimacy. Journal of Business Ethics, Vol } \\
\text { 95, pp. 1-21. }\end{array}$ & Moderate \\
\hline $\begin{array}{l}\text { Watson, T., Osborne-Brown, S. \& Longhurst, M. 2002. Issues } \\
\text { Negotiation - investing in stakeholders. Corporate Communi- } \\
\text { cations: An International Journal, Vol } 7 \text { No 1, pp. 54-61. }\end{array}$ & High \\
\hline $\begin{array}{l}\text { Gelbrich, K. 2010. Anger, frustration and helplessness after } \\
\text { service failure: coping strategies and effective informational } \\
\text { support. Journal of the Academy of Marketing Science, Vol 38, } \\
\text { pp. 567-585. }\end{array}$ & High/moderate \\
\hline $\begin{array}{l}\text { Heath, P. \& Milne, D. 2002. Making quality everyone's business: } \\
\text { a case study of partnership in primary care. International Journal } \\
\text { of Health Care Quality Assurance, Vol } 15 \text { No 3, pp. 99-105. }\end{array}$ & High/moderate \\
\hline $\begin{array}{l}\text { Lähteenmäki, S. \& Laiho, M. 2011. Global HRM and the } \\
\text { dilemma of competing stakeholder interests. Social } \\
\text { Responsibility Journal, Vol } 7 \text { No 2, pp. 166-180. }\end{array}$ & High/moderate \\
\hline $\begin{array}{l}\text { McColl-Kennedy, J. R., Sparks, B. A. \& Nguyen, D. T. } 2011 . \\
\text { Customer's angry voice: Targeting employees or the organi- } \\
\text { sation? Journal of Business Research, Vol 64, pp. 707-713. }\end{array}$ & High/moderate \\
\hline $\begin{array}{l}\text { Patterson, P. G., McColl-Kennedy, J. R., Smith, A. K. \& Lu, Z. } \\
\text { 2009. Customer Rage: Triggers, Tipping points and Take-outs. } \\
\text { California Management Review, Vol } 52 \text { No 1, pp. 6-29. }\end{array}$ & High/moderate \\
\hline $\begin{array}{l}\text { Strizhakova, Y., Tsarenko, Y. \& Ruth, J. A. 2012. "I'm Mad and } \\
\text { I Can’t Get That Service Failure Of My Mind.”: Coping and } \\
\text { Rumination as Mediators of Anger Effects on Customer Inten- } \\
\text { tions. Journal of Service Research, Vol } 15 \text { No 4, pp. 414-429. }\end{array}$ & High/moderate \\
\hline $\begin{array}{l}\text { Surachartkumtonkun, J., Patterson, P. G. \& McColl-Kennedy, J. } \\
\text { R. 2013. Customer Rage Back-Story: Linking Needs-Based } \\
\text { Cognitive Appraisal to Service Failure Type. Journal of } \\
\text { Retailing, Vol } 89 \text { No 1, pp. 72-87. }\end{array}$ & High/Moderate \\
\hline $\begin{array}{l}\text { Walker, D. H. T. } 2000 \text {. Client/customer or stakeholder focus? } \\
\text { ISO } 14000 \text { EMS as construction industry case study. The TQM } \\
\text { Magazine, Vol } 12 \text { No 1, pp. 18-25. }\end{array}$ & High/moderate \\
\hline
\end{tabular}

The articles were next analysed via Baker and Martinson's (2001) TARES framework of ethics. The framework was merely used as a tool to explore the kind of ethical issues arising and guided during the content analysis. The TARES refers to five principles including: Truth- 
fulness (of the message), Authenticity (of the persuader), Respect (for the persuadee), Equity (of the persuasive appeal) and Social Responsibility (for the common good). Thus, as the framework drew concrete details it also guided us during the content analysis.

The results show that organisations are more often to blame for stakeholder anger. Based on the limited cases analysed, it was possible to draw a connection between unethical behaviour and stakeholder anger. The TARES framework will benefit from a supplementation of the receiver point of view. Thus, Table 2 categorises unethical organisational actions leading to stakeholder anger. Those articles from Table 1 identified as high organisational degree of control have been selected for closer analysis.

\section{Table 2. Articles where organisations were to blame analysed with the TARES framework}

\begin{tabular}{|c|c|c|}
\hline $\begin{array}{l}\text { TARES } \\
\text { principles } \\
\text { breached }\end{array}$ & Article & Unethical persuasive action of an organization \\
\hline $\begin{array}{l}\text { Authenticity } \\
\text { Respect } \\
\text { Equity }\end{array}$ & $\begin{array}{l}\text { Alkayid, } \\
\text { Hasan \& } \\
\text { Meloche } \\
(2009)\end{array}$ & $\begin{array}{l}\text { Clinicians in Intensive Care Units (ICU's): ill patients } \\
\text { surrogate family members are not informed well enough } \\
\text { on ICU's web service. Lack of verbal communication } \\
\text { between clinicians and family members. }\end{array}$ \\
\hline $\begin{array}{l}\text { Respect } \\
\text { Equity }\end{array}$ & $\begin{array}{l}\text { Coombs \& } \\
\text { Holladay } \\
(2012)\end{array}$ & $\begin{array}{l}\text { Amazon.com's Kindle crisis case: Absence of } \\
\text { explanation for the deletion of e-books and a late online } \\
\text { apology by the management concerning the deletion. }\end{array}$ \\
\hline $\begin{array}{l}\text { Respect } \\
\text { Equity } \\
\text { Social } \\
\text { responsibility }\end{array}$ & Dhir (2006) & $\begin{array}{l}\text { Corporate violent rhetoric: dehumanizes the } \\
\text { intended targets, distances the individuals, and } \\
\text { compromises socially responsible corporate behavior. }\end{array}$ \\
\hline $\begin{array}{l}\text { Truthfulness } \\
\text { Respect } \\
\text { Equity } \\
\text { Social } \\
\text { responsibility }\end{array}$ & $\begin{array}{l}\text { Ihlen \& } \\
\text { Berntzen, } \\
(2007)\end{array}$ & $\begin{array}{l}\text { Norwegian oil industry lobbying for tax amendment: } \\
\text { Talked about hardships when making more profits than } \\
\text { ever before. Failed to appreciate the points-of-view, } \\
\text { the needs, and the rationality of the stakeholders. } \\
\text { Industry had an exaggerated faith in its own rational } \\
\text { argument, thus making it appear arrogant in the } \\
\text { eyes of politicians and public officials. }\end{array}$ \\
\hline $\begin{array}{l}\text { Respect } \\
\text { Equity }\end{array}$ & $\begin{array}{l}\text { Linsley \& } \\
\text { Slack (2012) }\end{array}$ & $\begin{array}{l}\text { The case of Northern Rock Bank: } \\
\text { Lack of an ethic of care on pre- and post-crisis } \\
\text { situations. Blaming external issues for the crisis. }\end{array}$ \\
\hline $\begin{array}{l}\text { 1) } \\
\text { - Truthfulness } \\
\text { - Social } \\
\text { responsibility } \\
\text { 2) } \\
\text { - Truthfulness } \\
\text { - Respect } \\
\text { - Equity } \\
\end{array}$ & $\begin{array}{l}\text { Watson } \\
\text { (2007) }\end{array}$ & $\begin{array}{l}\text { Two separate crisis situation cases (leading to failure): } \\
\text { 1) Ansett Airlines: } \\
\text { Senior executive staff unable to tell the truth to } \\
\text { customers concerning safety issues. } 20 \text { million spent on } \\
\text { ad-campaign instead of aircraft maintenance. } \\
\text { 2) Rover: } \\
\text { Rover's owner BMW lies about reorganization and } \\
\text { gives misinformation that it won't sell the Rover. }\end{array}$ \\
\hline
\end{tabular}




\begin{tabular}{|l|l|l|}
\hline $\begin{array}{l}\text { Respect } \\
\text { Social } \\
\text { responsibility }\end{array}$ & $\begin{array}{l}\text { Watson, } \\
\text { Osborne- } \\
\text { Brown \& } \\
\text { Longhurst } \\
(2002)\end{array}$ & $\begin{array}{l}\text { Unrecognizing potential issues and dealing with them } \\
\text { effectively. Case Royal Dutch Shell: Not informing } \\
\text { people about dumping activities at Brent Spar offshore. } \\
\text { Lack of information was eventually worse than the } \\
\text { activities itself. }\end{array}$ \\
\hline
\end{tabular}

Our results show that lack of respect for stakeholders and customers was the most common ground for stakeholder anger and negative engagement, apparent in all seven articles analysed. Similarly, equity or the lack of fairness was the second most common apparent in six cases. There were also cases of lacking truthfulness and social responsibility, as well as on case of lack of authenticity. Though these resulted from the limited, preliminary study, they do give direction as to what kind of organisational behaviours cause hateholding.

\section{Conclusion and discussion}

The aim of this study was to shed light on the negative engagement of stakeholders and the ethics related organisational actions causing stakeholder anger. The results yielded that organisations were mostly to blame in cases of negative stakeholder engagement, and that unethical behaviour was common in cases of stakeholder anger. Individuals react differently, and the same negative experience may lead to different types of negative engagement or lack of it. Destructive negative word of mouth has a more negative effect than constructive negative word of mouth (Wetzer et al., 2007) and calls for organisations to invite and acknowledge continuous stakeholder feedback. Results showed that in most hateholder cases, the organisations were somehow to blame. This seems to highlight the lack of strategic communication in the cases studied and underscores the need for increased monitoring of the online environment. Beyond the individuals affected, negative engagement or hateholder messages could remain online long after their original publication (Coombs \& Holladay, 2007) and even contain false information (Hardaker, 2010).

Since the way negative engagement is expressed is important (Simola, 2009; Turner, 2007), it will increasingly be the task of public relations professionals to enable feedback and receive stakeholders' complaints before they become hateholders. Previous studies have noted how taking blame might decrease the power of negative engagement (Simola, 2009) and lessen anger if the receiver's situation is heard and accepted (Turner, 2007), thus supporting the notion that organizations should admit responsibility when necessary. Such admitting was not apparent in the cases studied in this research. Regarding organisational strategies toward hateholders, the importance of dialogue has to be 
emphasised. The aim of public relations in the online environment will increasingly be to keep stakeholders from turning into hateholders. Once negative information is publicly online, different users may refer to it and cause the already resolved issue to stir more anger (Chu \& Kim, 2011; Coombs \& Holladay, 2007). The results of this study showed that passive or unresponsive organisations make stakeholder anger worse.

This study was a preliminary attempt to understand hateholder activity, and has several limitations. First, the data is merely based on a review of previous studies, not on current stakeholder anger cases. Second, the TARES framework applied in the analysis takes the perspective of the communicator without acknowledging the ethical obligations of the receiver (Baker \& Martinson, 2001), and as such was perhaps not the ideal match for the data. Third, it is possible that some relevant literature was missing due to its unavailability in the databases or the use of different concepts. Fourth, literature reviews rely on inclusion processes which are always based on subjective elections. This effect was reduced through transparency of choice and clarity of reporting. Moreover, the analysis process in qualitative research is open to various interpretations (Jesson et al., 2011; Hirsjärvi et al., 2009). Fifth, the literature chosen was not originally constructed with a focus on stakeholder anger. Instead, the phenomenon of stakeholder anger emerged through the critical and analytical reading of the literature during the review process. The literature also dealt with customers who could be considered either regular stakeholders or dissatisfied stakeholders. The definitions of the different stakeholder levels were challenging, but for the sake of logic, their identification was necessary. Given these limitations, future studies should look into who the actual target of anger toward organisations was: it was not obvious from our analysis whether the hateholder anger was aimed at individuals within the organisations (employees) or the organisations as a whole. Moreover, it was unclear whether hateholders make such distinctions, and whether it matters for negative engagement.

\section{References}

Alkayid, K., Hasan, H., \& Meloche, J. A., "Simulating information exchanges to investigate the utility of public web sites", in Transforming Government: People, Process and Policy, 3 (3), 2009, pp. 271-288.

Baker S. \& Martinson, D. L., "The TARES Test: Five Principles for Ethical Persuasion", in Journal of Mass Media Ethics, 16 (2/3), 2001, pp. 148-175.

Bentele, G. \& Nothaft, H., "Strategic communication and the public sphere from a European perspective", in International Journal of Strategic Communication, 4 (2), 2010, pp. 93-116. 
Bishop, J., "Representations of 'trolls' in mass media communication: A review of media-texts and moral panics relating to 'internet trolling", in International Journal of Web Based Communities, 10 (1), 2014, pp. 7-24.

Bowden-Everson, J. \& Naumann, K., Us versus them: The operation of customer engagement and customer disengagement within a local government service setting, paper presented at the Anzmac 2013 Conference, Auckland, New Zealand, 2013.

Brijs, T., Swinnen, G., Vanhoof, K. \& Wets, G., "Comparing complete and partial classification for identifying latently dissatisfied customers", in Lecture Notes in Computer Science, 1810, 2000, pp. 88-95.

Brodie, R. J., Hollebeek, L. D., Juric, B. \& Ilic, A., "Customer engagement: Conceptual domain, fundamental propositions, and implications for research", Journal of Service Research, 14 (3), 2011, pp. 252-271.

Brodie, R. J., Ilic, A, Juric, B. \& Hollebeek, L. D., "Consumer engagement in a virtual brand community: An exploratory analysis", in Journal of Business Research, 66 (1), 2013, 105-114.

Buckels, E. E., Trapnell, P. D. \& Paulhus, D. L., "Trolls just want to have fun. Personality and Individual Differences", in Personality and Individual Differences, 67, 2014, pp. 97-102.

Calder, B. J., Malthouse, E. C. \& Schaedel, U., "An experiential study of the relationship between online engagement and advertising effectiveness", in Journal of Interactive Marketing, 23 (4), 2009, pp. 321-331.

Cedereviciute, K. \& Valentini, C., "Towards a more holistic stakeholder analysis approach. Mapping known and undiscovered stakeholders from social media", in International Journal of Strategic Communication, 5 (4), 2011, pp. 221-239.

Champoux, V., Durgee, J. \& McGlynn, L., "Corporate Facebook pages: When 'fans' attack”, Journal of Business Strategy, 33 (2), 2012, pp. 22-30.

Chen, Z. \& Lurie, N. H., "Temporal contiguity and negativity bias in the impact of online word-of-mouth", Journal of Marketing Research, 50 (4), 2013, pp. 463-475.

Chu, S.-C. \& Kim, Y., "Determinants of consumer engagement in electronic word-of-mouth (eWom) in social networking sites", in International Journal of Advertising, 30 (1), 2011, pp. 47-75.

Coombs, W. T. \& Holladay, S. J., “Amazon.com's Orwellian nightmare: Exploring apology in an online environment", in Journal of Communication Management, 16 (3), 2012, pp. 280-295.

Coombs, W. T. \& Holladay, S. J., "The negative communication dynamic Exploring the impact of stakeholder affect on behavioral intentions", in Journal of Communication Management, 11 (4), 2007, pp. 300-312.

Cullinan, C., Bline, D., Farrar, R. \& Lowe, D., "Organization-Harm vs. Organization- Gain Ethical Issues: An Exploratory Examination of the Effects of Organizational Commitment", in Journal of Business Ethics 80, 2008, pp. 225-235. 
Dhir, K., "Corporate communication through nonviolent rhetoric", in Corporate Communications, 11 (3), 2006, pp. 249-266.

Fawkes, J. (2007). "Public relations models and persuasion ethics: a new approach", in Journal of Communication Management, 11 (4), 2007, pp. 313-331.

Fink, A., Conducting Research Literature Reviews: From the Internet to the Paper, Thousand Oaks (CA), Sage, 2010.

Fosdick, H., "Why people troll and how to stop them", 2012, retrieved from http://www.osnews.com/story/25540.

Freeman, R. E., Strategic Management: A Stakeholder Approach, Boston (MA), Pitman, 1984.

Freeman, R. E., Harrison, J. S., Wicks, A. C., Parmar, B. \& de Colle, S., Stakeholder Theory: The State of the Art, Cambridge (UK), Cambridge University Press, 2010.

Gelbrich, K., "Anger, frustration and helplessness after service failure: Coping strategies and effective informational support", in Journal of the Academy of Marketing Science, 38, 2010, pp. 567-585.

Gummerus, J., Liljander, V., Weman, E. \& Pihlströn, M., "Customer engagement in a Facebook brand community", in Management Research Review, 35(9), 2012, pp. 857-877.

Hardaker, C., "Trolling in asynchronous computer-mediated-communication", in Journal of Politeness Research, 6, 2010, pp. 215-242.

Heath, P. \& Milne, D., “Making quality everyone's business: A case study of partnership in primary care", in International Journal of Health Care Quality Assurance, 15 (3), 2002, pp. 99-105.

Heinonen, K., "Consumer activity in social media: Managerial approaches to consumers' social media behavior", in Journal of Consumer Behavior, 10 (6), 2011, pp. 356-364.

Hennig-Thurau, T., Gwinner K., Walsh, G. \& Gremler, D., "Electronic word-ofmouth via consumer-opinion platforms: What motivates consumers to articulate themselves on the internet?", in Journal of Interactive Marketing, 18 (1), 2004, pp. 38-52.

Hickson, K., "Ethical issues in practising public relations in Asia", in Journal of Communication Management, 8 (4), 2003, pp. 345-353.

Hirschman, A. O, Exit, Voice, and Loyalty: Responses to Decline in Firms, Organizations, and States, Cambridge (MA), Harvard University Press, 1970.

Hirsjärvi, S., Remes, P. \& Sajavaara, P., Tutki ja kirjoita. 15., uudistettu painos, Kirjayhtymä Oy, Kariston Kirjapaino Oy, Hämeenlinna, 2009.

Huo, Y. J., Binning, K. R. \& Molina, L. E., "Testing an integrative model of respect: Implications for social engagement and well-being", in Personality and Social Psychology Bulletin, 36 (2), 2010, pp. 200-212. 
Ihlen, O. \& Berntzen, O., "When lobbying backfires: Balancing lobby efforts with insights from stakeholder theory", in Journal of Communication Management, 11 (3), 2007, pp. 235-246.

Jahn, B. \& Kunz, W., "How to transform consumers into fans of your brand", in Journal of Service Management, 23 (3), 2012, pp. 322-361.

Javornik, A. \& Mandelli, A., "Behavioral perspectives of customer engagement: An exploratory study of customer engagement with three Swiss FMCG brands", in Database Marketing \& Customer Strategy Management, 19 (4), 2012, pp. 300-310.

Jesson, J. K, Matheson, L. \& Lacey, F. M., Doing your literature review Traditional and systematic technique, Thousand Oaks (CA), Sage, 2011.

Jin, Y., Pang, A. \& Cameron, G. T., "The role of emotions in crisis responses. Inaugural test of integrated crisis mapping (ICM) model", in Corporate Communications, 15 (4), 2010, pp. 428-452.

Johansen, T. S., \& Nielsen, A. E., "Strategic stakeholder dialogues: A discursive perspective on relationship building", in Corporate Communications, 16 (3), pp. 204-217.

Keane, T. P., "Exploring stakeholder emotional intelligence", in Management Research News, 29 (3), 2006, pp. 128-138.

Kent, M. \& Taylor, M., "Toward a dialogic theory of public relations", in Public Relations Review, 28 (2), 2002, pp. 21-37.

Kerley, R., "Controlling urban car parking - an exemplar for public management?", in International Journal of Public Sector Management, 20 (6), 2007, pp. 519-530.

Kiely, T., "Tapping into Mammon: Stakeholder perspectives on developing church tourism in Dublin's Liberties", in Tourism Review, 68 (2), 2012, pp. 31-43.

Kizza, J. M., Ethical and Social Issues in the Information Age, London et al., Springer, 2013.

Lindenmeier, J., Tscheulin, D. K., \& Drevs, F., "The effects of unethical conduct of pharmaceutical companies on consumer behavior. Empirical evidence from Germany", in International Journal of Pharmaceutical and Healthcare Marketing, 6 (2), 2012, pp. 108-123.

Linsley, P. M., \& Slack, R. E.,"Crisis management and an ethic of care: The case of Northern Rock Bank", in Journal of Business Ethics, 113, 2013, pp. 285-295.

Loewenstein, G., "Out of Control: Visceral Influences on Behavior", in Organizational Behavior and Human Decision Process, 65 (3), 1996, pp. 272-292.

Luoma-aho, V., Emotional stakeholders: A threat to organizational legitimacy?, paper presented at the ICA Conference 2010, Singapore, retrieved from http://jyu.academia.edu/VilmaLuomaaho/Papers/185612/Emotionalstakeholders--A-Threat-to-Organizational-Legitimacy- 
Luoma-aho, V. \& Paloviita, A., "Actor-networking stakeholder theory for today's corporate communications", in Corporate Communications, 15 (1), 2010, pp. 49-67.

Luoma-aho, V. \& Vos, M. (2010). "Towards a more dynamic stakeholder model: acknowledging multiple issue arenas", in Corporate Communications, 15 (3), 2010, pp. 315-331.

Mangold, W. G. \& Faulds, D. J., "Social media: The new hybrid element of the promotion mix", in Business Horizons, 52 (4), 2009, pp. 357-365.

McColl-Kennedy, J. R., Sparks, B. A. \& Nguyen D. T., "Customers angry voice: Targeting employees or the organization?", in Journal of Business Research, 64, 2011, pp. 707-713.

McDonald, L. M., Sparks, B. \& Glendon, A. I., "Stakeholder reactions to company crisis communication and causes", in Public Relations Review, 36, 2010, pp. 263-271.

Men, R. \& Tsai, W., "How companies cultivate relationships with publics on social network sites: Evidence from China and the United States", in Public Relations Review, 38 (5), 2012, pp. 723-730.

Mersey, R. D., Malthouse, E. D. \& Calder, B. J., "Engagement with online media", Journal of Media Business Studies, 7 (2), 2010, pp. 39-56.

Messina, A., "Public relations, the public interest and persuasion: an ethical approach", in Journal of Communication Management, 11 (1), 2007, pp. 2952.

Mollen, A. \& Wilson, H.,"Engagement, telepresence and interactivity in online consumer experience: Reconciling scholastic and managerial perspectives", in Journal of Business Research, 63 (9/10), 2010, pp. 919-925.

Muntinga, D. G., Moorman, M. \& Smit, E. G., "Introducing COBRAs: Exploring motivations for brand-related social media use", International Journal of Advertising, 30 (1), 2011, pp. 13-46.

Ojala, J. \& Luoma-aho, V., "Stakeholder relations as social capital in early modern international trade", in Business History, 50 (6), 2008, pp. 749-764.

Pace, K. M., Fediuk, T. A. \& Botero, I. C., "The acceptance of responsibility and expressions of regret in organizational apologies after a transgression", in Corporate Communications, 15 (4), 2010, 410-427.

Pagani, M., \& Mirabello, A., "The influence of personal and social-interactive engagement in social TV web sites", in International Journal of Electronic Commerce, 16 (2), 2011, pp. 41-67.

Parsons, P. J., Ethics in Public Relations: A Guide to Best Practice, London, Kogan Page, 2004.

Patterson, P. G., McColl-Kennedy, J. R., Smith, A. K. \& Lu, Z., "Customer rage: Triggers, tipping points and take-outs", in California Management Review, 52 (1), 2009, pp. 6-29.

Sashi, C. M., "Customer engagement, buyer-seller relationships, and social media”, in Management Decision, 50 (2), 2012, pp. 253-272. 
Sedereviciute, K. \& Valentini, C., "Towards a more holistic stakeholder analysis approach. Mapping known and undiscovered stakeholders from social media", in International Journal of Strategic Communication, 5 (4), 2011, pp. 221-239.

Simola, S.-K., "Anti-corporate activist anger: Inappropriate irrationality or social change essential?", in Society and Business Review, 4 (3), 2009, pp. 215-230.

Sloan, P. \& Oliver, D., "Building trust in multi-stakeholder partnerships: Critical emotional incidents and practices of engagement", in Organization Studies, 34 (12), 2013, pp. 1835-1868.

Smith, S. D., Juric, B. \& Niu, J., Negative Consumer Brand Engagement: An Exploratory Study of "I Hate Facebook" Blogs, paper presented at the Anzmac 2013 Conference, Auckland, New Zealand, 2013.

Stein, N. L. \& Levine, L. J., "Making sense out of emotion: The representation and use of goal-structured knowledge", in Stein, N. L., Leventhal, B. \& Trabasso, T. (eds.), Psychological and biological approaches to emotion, Hillsdale, NJ: Erlbaum, 1990, pp. 45-73.

Strizhakova, Y., Tsarenko, Y. \& Ruth, J. A., "'I'm Mad and I Can't Get That Service Failure Of My Mind': Coping and Rumination as Mediators of Anger Effects on Customer Intentions", in Journal of Service Research, 15 (4), 2012, pp. 414-429.

Surachartkumtonkun, J., Patterson, P. G. \& McColl-Kennedy, J. R., "Customer rage back-story: Linking needs-based cognitive appraisal to service failure type", in Journal of Retailing, 89 (1), 2013, pp. 72-87.

Swenson-Lepper, T., "Ethical Sensitivity for Organizational Communication Issues: Examining Individual and Organizational Differences", in Journal of Business Ethics, 59, 2005, pp. 205-231.

Turner, M. M., "Using emotion in risk communication: The Anger Activism Model", in Public Relations Review, 33, 2007, pp. 114-119.

Van Doorn, J., Lemon, K. N., Mittal, V., Nass, S., Pick, D., Pirner, P. \& Verhoef, P. C., "Customer engagement behavior: Theoretical foundations and research directions", in Journal of Service Research, 13 (3), 2010, pp. 253-266.

Vivek, S. D., Beatty, S. E. \& Morgan, R. M., "Customer engagement: Exploring customer relationships beyond purchase", in Journal of Marketing Theory and Practice, 20 (2), 2012, pp. 127-145.

Vos, M., Schoemaker, H. \& Luoma-aho, V., "Setting the agenda for research on issue arenas", in Corporate Communications, 19 (2), 2014, pp. 200-215.

Walker, D. H. T., "Client/customer or stakeholder focus? ISO 14000 EMS as construction industry case study", in TQM Magazine, 12 (1), 2000, pp. 1825 .

Watson, T., "Reputation and ethical behavior in a crisis: predicting survival", in Journal of Communication Management, 11 (4), 2007, pp. 371-384. 
Watson, T., Osborne-Brown, S. \& Longhurst, M., "Issues negotiation Investing in stakeholders", Corporate Communications, 7 (1), 2002, pp. 5461.

Wetzer, I. M., Zeelenberg, M. \& Pieters, R., "'Never eat in that restaurant I did!': Exploring why people engage in negative word-of-mouth communication", in Psychology \& Marketing, 24 (8), 20078, pp. 661-680.

Zeelenberg, M. \& Pieters, R., "Beyond valence in customer dissatisfaction: A review and new findings on behavioral responses to regret and disappointment in failed services", in Journal of Business Research, 57, 2004, pp. 445-455.

Zerfass, A., Moreno, A., Tench, R., Vercic, D. \& Verhoeven, P., European Communication Monitor 2013. A changing landscape - Managing crises, digital communication and $C E O$ positioning in Europe. Results of a survey in 43 countries, Brussels, EUPRERA/EACD, Helios Media, 2013. 


\section{AUTHORS:}

Matias Lievonen, M.A., is project researcher at the Agora Center at the University of Jyväskylä, Finland, and a $\mathrm{PhD}$ researcher at the Department of Communication of the same university. His research interests include negative stakeholder engagement, hateholders, negative customer experiences and behaviours, and customer reconciliation processes.

Vilma Luoma-aho, Dr., is Professor of Organizational Communication and PR at the Department of Communication at University of Jyväskylä, Finland. Her research interests include stakeholder relations and intangible assets. Currently, she leads two research projects at her university, one on transparency of new forms of advertising and the other on negative stakeholder engagement. 